\title{
Polyp dropout in a solitary cold-water coral
}

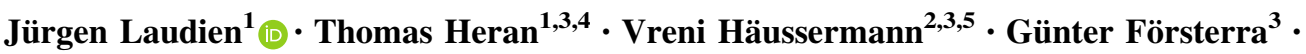 \\ Gertraud M. Schmidt-Grieb ${ }^{1}$ Claudio Richter ${ }^{1,4}$
}

Received: 27 March 2020/Accepted: 22 June 2021/Published online: 6 August 2021

(C) The Author(s) 2021

\begin{abstract}
Scleractinian corals feature both sessile and mobile stages and diverse modes of development. In some cases, development can be reversed. Examples include polyp detachment in response to environmental stress (bailout or polyp expulsion) and reverse metamorphosis, where juveniles detach from the primary skeleton and revert to the mobile stage. Here, we provide aquaria and field evidence of a new form of reverse development: polyp dropout in the solitary cold-water coral Caryophyllia huinayensis. It features tissue retraction and detachment of an entire adult polyp from the skeleton in the putative absence of a stressor. The dropout polyp remains viable and continues to live for many weeks, albeit in a rather collapsed state lacking a well-developed hydroskeleton. We carried out a long-term (37 months) rearing experiment under constant aquaria conditions and found polyp dropout in four out of 83 individuals. Detachment was accompanied by the extrusion of mesenterial filaments through perforations in
\end{abstract}

Topical Editor: Aanastazia Teresa Banaszak

Jürgen Laudien

juergen.laudien@awi.de

1 Alfred Wegener Institute Helmholtz Centre for Polar and Marine Research, 27515 Bremerhaven, Germany

2 Facultad de Economía y Negocios, Universidad San Sebastián, Lago Panguipulli, 1390 Puerto Montt, Chile

3 POETA Program (Programa de Observación de los Ecosistemas Terrestres y Acuáticos), Pontificia Universidad Catolica de Valparaiso, Escuela de Ciencias del Mar, Avda. Brasil, 2950 Valparaíso, Chile

4 University of Bremen, Bibliothekstraße 1, 28359 Bremen, Germany

5 Fundacion San Ignacio del Huinay, Casilla, 462 Puerto Montt, Chile the body wall. We believe this resulted in the loss of the hydroskeleton, which prevented the dropouts to subsequently resettle or form a new skeleton. As opposed to other known forms of reverse development, the new form is not accompanied by reversible metamorphosis, abandonment of the colonial way of life, nor is it a survival or asexual reproduction strategy. We found field indications of polyp dropout in Patagonian field populations of C. huinayensis, where $1.4 \pm 0.8 \%$ (mean $\pm \mathrm{SD}, N=9322$ ) of the polyps of the natural population showed partial detachment indicative of imminent dropout in the putative absence of external impact. Polyp dropout is the first record of polyp detachment in a solitary CWC with possible repercussions for adult coral mobility, evolution and Stanley's (2003) 'naked coral' hypothesis.

Keywords Cold-water scleractinia $\cdot$ Caryophyllia huinayensis · Polyp detachment · Polyp dropout · Chilean Fjord Region · Asexual dispersal

\section{Introduction}

Corals are sessile animals with diverse modes of development, generally involving a mobile stage of dispersal, the planula larva, which later settles, undergoes metamorphosis and develops into the primary polyp (e.g. Richmond and Hunter 1990). Under environmental stress, development may become reverse. For example, a settled, calcified polyp may build back its radially compartmented body plan, reverse metamorphosis to become a mobile secondary larva, disperse with the currents and reattach elsewhere (Richmond 1985). Reverse development may also affect the colony: through ontogenetic reversal, genetic programs specific to earlier stages are reactivated, leading to back- 
transformation to the previous morph (called 'rejuvenation') resulting in resting developmental stages with inert metabolic functions (Piraino et al. 2004). Polyp detachment, including polyp expulsion and polyp bail-out, is another form of reverse development, where a sessile polyp abandons its initial structure and becomes mobile again, maintaining its biological organization. Both polyp expulsion and polyp bail-out have been reported from shallowwater colonial scleractinians. Polyp expulsion is observed in physiologically healthy corals inhabiting chronically physically disturbed environments. Here, whole polyps, including their calices, leave the colony to settle elsewhere (asexual reproduction). This process seems to be regulated by the colony (Kramarski-Winter et al. 1997). Polyp bailout, by contrast, refers to the escape of polyps without calices from a parent colony in response to acute environmental stress (e.g. Sammarco 1982; Kružić 2007; Capel et al. 2014; Serrano et al. 2018) and was also observed for octocoral species (Rakka et al. 2019; Wells and Tonra 2020). Thus, polyp bail-out provides a route of escape to new locations for possible resettlement. Additionally, fission (intratentacular budding), extratentacular budding (both with different modes), transverse division and asexual planula production have been reported for a number of tropical and temperate coral species as asexual reproduction modes (e.g. Cairns 1988; Tokuda et al. 2017), in some cases allowing the species to recover after external physical disturbance (Wilson 1979; Coppari et al. 2019). So far, the fragmentation of colony parts is the only reported asexual mode of dispersal in scleractinian cold-water corals (CWCs) (Wilson 1979; Le Goff-Vitry et al. 2004; Roberts et al. 2009; Dahl et al. 2012) and polyp detachment processes have not yet been described for solitary scleractinians.

Caryophylliidae are a diverse family of scleractinians with 269 species, colonizing water depths below $50 \mathrm{~m}$ (Roberts et al. 2009). Caryophyllia huinayensis Cairns et al. 2005 is a solitary, azooxanthellate member found in South Chile $\left(36^{\circ} \mathrm{S}\right.$ to $\left.51^{\circ} \mathrm{S}\right)$ at water depths within the depth range 11-800 m (Fig. 1; Cairns et al. 2005; Häussermann and Försterra 2009; Sellanes et al. 2008). In spite of its small size ( $\leq 18.7 \mathrm{~mm}$ height and $\leq 8.7 \mathrm{~mm}$ calyx diameter), it is an important epibenthic component forming dense aggregations of up to $2211 \pm 180$ ind. $\mathrm{m}^{-2}$ on steep walls of fjords and channels between 16 and $265 \mathrm{~m}$ (Häussermann and Försterra 2007; Wurz 2014). In Comau Fjord, terrestrial runoff leads to a permanent halocline subjecting the corals at depth to hypoxic and hypercapnic conditions (Silva 2008; Fillinger and Richter 2013). As with most CWCs, very little is known about its biology and development. Here, the first field and aquaria observations of reverse development in a solitary, scleractinian CWC are reported: polyp dropout in $C$. huinayensis, where an

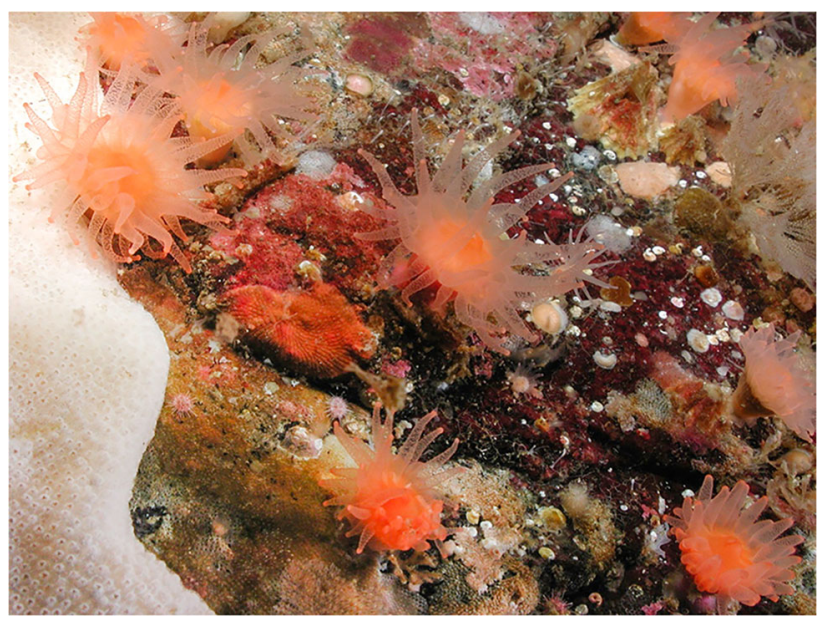

Fig. 1 Caryophyllia huinayensis at $21 \mathrm{~m}$ water depth (Comau Fjord, Southern Chile)

apparently unstressed, adult, solitary polyp shows tissue retraction, autonomously detaches as a unit from its skeleton and continues to live without calcium carbonate skeleton, with no visible fundamental modifications in its external body plan.

\section{Material and methods}

In February 2014, a total of 30 C. huinayensis specimens were collected by SCUBA divers from Comau Fjord (Patagonia, Chile). In March and May 2015, a second and third batch of 15 and 24 individuals were sampled, respectively. Specimens were chiselled off the substrate ( $\sim 21 \mathrm{~m}$ water depth, photic zone) and shipped in oxygenreplete seawater to Germany. After arrival $(<35 \mathrm{~h}$ from dispatch), corals were visually checked for polyp activity, tentacle appearance and colour ( $0 \%$ mortality) and maintained in two separate closed circuits (A and B; A: 30 individuals from 2014, B: 39 individuals from 2015) each filled with $285 \mathrm{~L}$ of artificial seawater mimicking the Comau Fjord environment at the sampling site of the corals (Online supplementary material 1). Corals were reared in the dark to avoid aquaria contamination with algae/cyanobacteria and thus repetitive cleaning which may cause stress. As populations of this species also occur in the aphotic zone (Sellanes et al. 2008), it is assumed that photoperiod is not of high importance for this species. The maintained corals were fed three times a week with live Artemia franciscana-nauplii and juvenile krill [one Euphausia pacifica/(ind. $\times$ week)] (Zierfischfutterhandel Norbert Erdmann e.K., Ritterhude, Germany). Each week, nutrient concentrations (nitrate, nitrite, phosphate and ammonium) were determined photometrically (Spectroquant ${ }^{\circledR}$ test, Merck KGaA, Darmstadt, Germany) just 
before a third of the water in each circuit was exchanged. Deviations between the water changes were $<5 \%$ of the respective target value.

During the study, adults of circuit A reproduced and 14 larvae settled on the aquarium glass in July 2015. The recruits (Calyx $\varnothing 2.3 \pm 0.3 \mathrm{~mm}$ ) were removed with razor blades without any visual damage, glued (Super Flex Glue Gel, UHU GmbH and Co KG, Bühl, Germany) on glass slides and maintained in circuit A. After this transfer, they grew at a similar rate $\left(3.4 \pm 1.9 \mathrm{~mm} \mathrm{a}^{-1}\right)$ as individuals in situ (Wurz 2014). This indicates good rearing conditions in the aquaria system.

Polyp appearance and activity were visually monitored on a daily basis. Based on that, polyps were classified to one of the following three stages: (1) Attached polypextended tissue in full contact with skeleton; (2) partially detached polyp-recession of tissue from lower to upper calyx and between septae and partial loss of contact of tissue with skeleton, with individual strands of tissue remaining; and (3) fully detached polyp-complete loss of contact with skeleton, tissue sinking to the bottom. The detached polyps were kept in Petri dishes $(\varnothing 10 \mathrm{~cm})$ submerged in the respective circuit and continued to be fed as specified above. Two of the detached polyps were inadvertently lost when cleaning circuit A five weeks after detachment, but one specimen (\#3, circuit B) was monitored for more than seven months. Specimens were examined under a stereomicroscope biweekly to check for reattachment, skeleton precipitation and polyp activity. In order to calculate potential in situ dispersal by currents, the sinking rate of this specimen was determined in five runs, five weeks after the detachment by transferring it to a gridded $350 \mathrm{~mm}$ cylinder and estimating the time it took the specimen to sink to the bottom.

During austral winter 2019, spring 2019 and summer 2019/2020, a field study was conducted by SCUBA divers at Comau Fjord (Cross-Huinay North, $42^{\circ} 23^{\prime} 12.8^{\prime \prime} \mathrm{S}$, $72^{\circ} 27^{\prime} 46.3^{\prime \prime} \mathrm{W}$ and Liliguapi $\left.42^{\circ} 9^{\prime} 43^{\prime \prime} \mathrm{S}, 72^{\circ} 35^{\prime} 55^{\prime \prime} \mathrm{W}\right)(3$ seasons $\times 2$ sites $=6$ transects) to determine the proportion of $C$. huinayensis undergoing polyp detachment in situ. Photographs were taken with a digital camera (Nikon D7000 DSLR, $24 \mathrm{~mm}$ lens, $19.5 \mathrm{~cm} \times 29.6 \mathrm{~cm}$ frame) between 24 and $27 \mathrm{~m}$ water depth along a horizontal 35-m line transect in $1 \mathrm{~m}$ intervals. C. huinayensis individuals were counted, and the polyps were classified into three stages of polyp detachment, described from the aquaria experiment: polyp attached; partially detached; and fully detached.

\section{Results and discussion}

This is the first report of reverse development in a scleractinian CWC. Four out of 83 aquarium specimens (4.8\%), two in each circuit, dropped out and exposed the white skeletons of the corallites (Fig. 2d, Online supplementary material 2). Microscopic examination of the vacated skeletons indicated that no tissue remained on them. The two dropouts of circuit A were former recruits (see Materials and Methods, now adults), and the two dropouts in circuit B were from wild corals. In one of the latter, the tissue began to recede twelve weeks before polyp dropout (Fig. 2, Online supplementary material 2,3). An additional adult individual (circuit B) showed tissue recession, however, remained partially attached for ten weeks (Fig. 2b, Online supplementary material 2,3). The other corals (A: $n=42$, B: $n=36$ ) remained attached. No unusual behaviour was observed neither before nor after the event in any of the attached fellow corals, so that contamination or disease in the rearing system seems unlikely, as it would have affected more individuals.

The observed polyp dropout in the solitary C. huinayensis is considered to be an autonomous detachment of a previously unstressed polyp. It is preceded by tissue retraction and leads to detachment of the entire adult polyp which subsequently lives on without a calcium carbonate skeleton in an unattached state. No fundamental changes in the external body plan are apparent, and the oral disc with the mouth and the tentacles as well as the mesenteries remain (Fig. 2a-c).

Polyp dropout differs from other reported forms of reverse development confined to stressed shallow-water colonial scleractinians in tropical, subtropical and temperate environments in a number of ways (Table 1). In contrast to (i) reversible metamorphosis (Richmond 1985) and (ii) ontogeny reversal (Piraino et al. 1996, 2004), polyp dropout is not accompanied by fundamental changes in the body plan. Polyp dropout also differs from (iii) polyp expulsion (Kramarski-Winter et al. 1997) and (iv) polyp bail-out (Sammarco 1982; Kružić 2007; Capel et al. 2014; Serrano et al. 2018). These are escape mechanisms of polyps from chronically physically disturbed (polyp expulsion) or acutely stressed disintegrating (polyp bailout) colonies, resulting in dispersal and, after successful resettlement, asexual reproduction. The latter requires an adult and a reproductive product, but in the case of polyp dropout, the whole adult moves away from its skeleton and there is no reproductive product. In contrast to the polyp detachment processes described so far, polyp dropout occurs in the absence of abiotic or biotic stressors and does not appear to be related to reproduction (Table 1). 
Fig. 2 Caryophyllia

huinayensis maintained in the aquarium system before $(\mathbf{a}, \mathbf{b})$ and after (c) polyp dropout, leaving behind a denuded skeleton (d). Some mesenterial filaments are exposed (b, c).

C. huinayensis in situ

(e-h) showing stages with receded tissue (f), exposed mesenterial filaments (g) and bare skeleton (h). In photographs a-d, the background was replaced with black (free-form select); for raw images, see Laudien et al. (2019), m: mouth, mf: mesenterial filaments, od: oral disc, t: tentacles
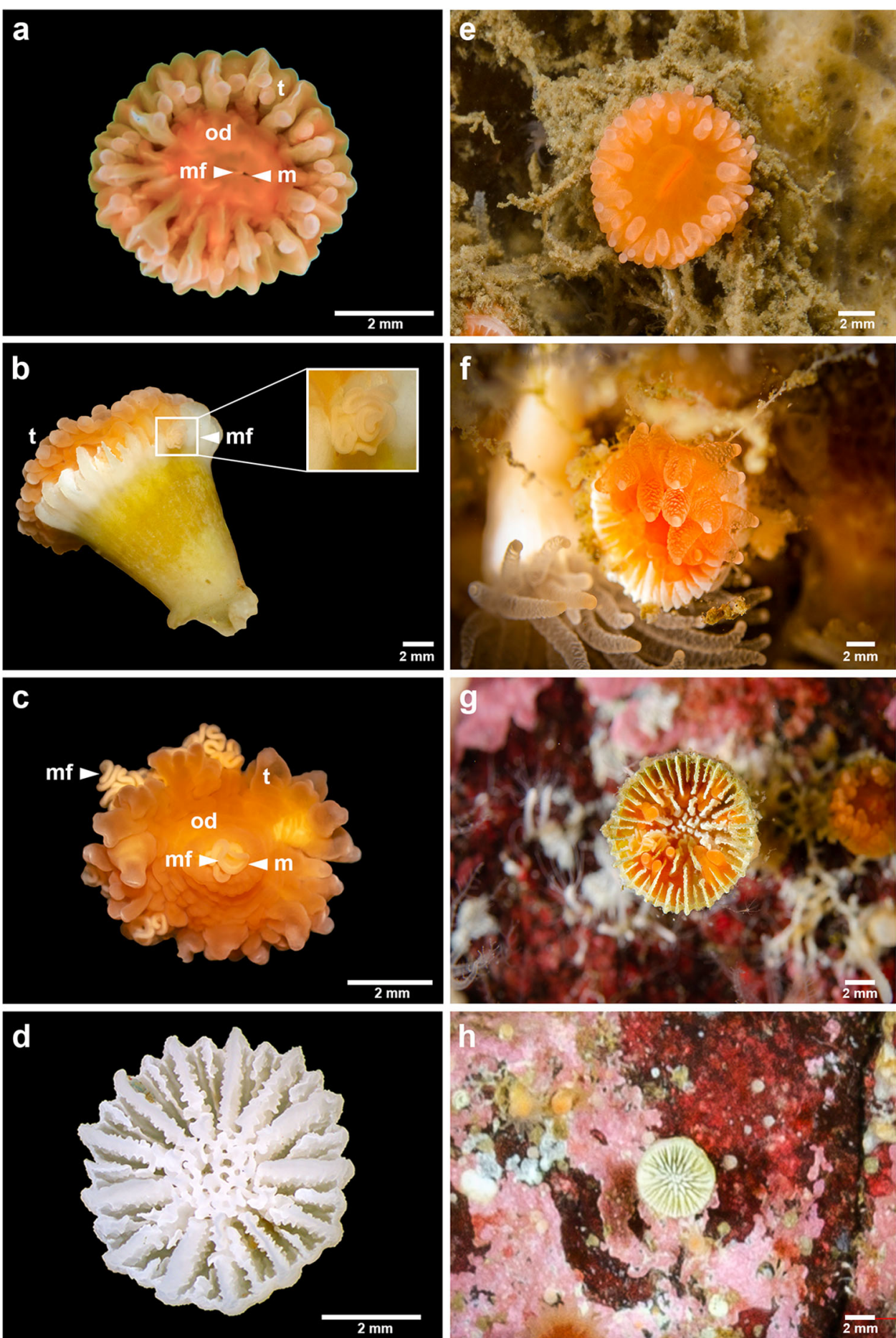

The dropout polyps had a constricted appearance with mesenterial filaments protruded apically through the mouth, but also laterally through the body wall (Fig. 2c). While the apical exposure is not uncommon, the later feature is absent in attached specimens not least because of the barrier built by the calcareous skeleton. The behaviour of the mesenterial filaments (e.g. whether they can be retracted and the openings in the body wall can be closed again) cannot be described because a more detailed examination would have caused a disturbance for the polyp. Similar observations of protruded mesenterial filaments were reported for detached polyps of the tropical scleractinian Mussa angulosa (Goreau et al. 1971) and planula larvae of Pocillopora damicornis, when the formation of an organic film was prevented in an attempt to keep the larvae from settling (Richmond 1985). Also, some 
Table 1 Reported stressors causing polyp detachment in scleractinian corals and likelihood of their involvement in the observed detachment of Caryophyllia huinayensis

\begin{tabular}{|c|c|c|c|c|c|}
\hline Stressor & Species & $\begin{array}{l}\text { Climatic } \\
\text { zone }\end{array}$ & Reference & $\begin{array}{l}\text { Probability for } \\
\text { the present } \\
\text { event }\end{array}$ & Justification \\
\hline Low oxygen & $\begin{array}{l}\text { Seriatopora hystrix } \\
\text { Pocillopora damicornis }\end{array}$ & Tropics & $\begin{array}{l}\text { Sammarco (1982) } \\
\text { Richmond (1985) }\end{array}$ & Very unlikely & $\begin{array}{l}\text { Minimal concentration of oxygen } \\
8.33 \mathrm{mg} / \mathrm{l} \text {, water circulated } \\
\text { constantly, (Comau Fjord: } \\
4-12 \mathrm{mg} / \mathrm{l}) ; 2 \text { h hypoxia did not } \\
\text { cause detachment (A. Castrillon, } \\
\text { pers. comm.) }\end{array}$ \\
\hline \multirow{4}{*}{$\begin{array}{l}\text { High/low } \\
\text { temperature }\end{array}$} & Acropora tenuis & Tropics & Yuyama et al. (2012) & \multirow{4}{*}{$\begin{array}{l}\text { Unlikely, unless } \\
\text { one assumes } \\
\text { that reduced } \\
\text { variability } \\
\text { induces change }\end{array}$} & \multirow{4}{*}{$\begin{array}{l}\text { Temperature was monitored } \\
\text { constantly in a climatized cool } \\
\text { room; measured values ranged } \\
\text { between } 12.0 \text { and } 13.3{ }^{\circ} \mathrm{C}, \\
\text { without seasonal variation } \\
\text { (Comau Fjord: } 9.5-16{ }^{\circ} \mathrm{C} \text { ) }\end{array}$} \\
\hline & $\begin{array}{l}\text { Pocillopora damicornis } \\
\text { Favia favus }\end{array}$ & Subtropics & $\begin{array}{l}\text { Fordyce et al. (2017) } \\
\text { Kramarsky-Winter et al. } \\
\quad(1997)\end{array}$ & & \\
\hline & Cladocora caespitosa & $\begin{array}{l}\text { Temperate } \\
\text { region }\end{array}$ & Kružić (2007) & & \\
\hline & Oculina patagónica & $\begin{array}{l}\text { Temperate } \\
\text { region }\end{array}$ & $\begin{array}{l}\text { Kramarsky-Winter et al. } \\
\text { (1997) }\end{array}$ & & \\
\hline High/low salinity & Pocillopora damicornis & Tropics & $\begin{array}{l}\text { Shapiro et al. (2016) } \\
\text { Liu et al. (2020) }\end{array}$ & Very unlikely & $\begin{array}{l}\text { Salinity of new water introduced to } \\
\text { the system was measured and } \\
\text { adjusted; values of the water in } \\
\text { the system ranged between } 30.4 \\
\text { and } 33.2 \text { reflecting the natural } \\
\text { salinity range in the coral's } \\
\text { habitat (see Table Online } \\
\text { supplementary material 1). There } \\
\text { were no abrupt changes in salinity } \\
\text { in the aquarium system }\end{array}$ \\
\hline High/low pH & Pocillopora damicornis & Tropics & Kvitt et al. (2015) & Very unlikely & $\begin{array}{l}\text { The } \mathrm{pH} \text { of the maintenance water and } \\
\text { that of new water introduced to the } \\
\text { system during water exchange are } \\
\text { controlled and ranged between } 7.8 \\
\text { and } 8.0 \text { reflecting the natural } \mathrm{pH} \\
\text { range in the coral's habitat (see } \\
\text { Table Online supplementary material } \\
\text { 1). There were no abrupt changes in } \\
\mathrm{pH} \text { in the aquarium system }\end{array}$ \\
\hline \multirow[t]{2}{*}{ Sedimentation } & Favia favus & Subtropics & $\begin{array}{l}\text { Kramarsky-Winter et al. } \\
\text { (1997) }\end{array}$ & Very unlikely & \multirow{2}{*}{$\begin{array}{l}\text { Water was constantly, } \\
\text { automatically treated, and no } \\
\text { sediment was added to the } \\
\text { system; sediment stress } \\
\text { experiments (sediment: } \\
\text { water = 1: } 1000 \text { ) did not cause } \\
\text { detachment (unbub. data.) }\end{array}$} \\
\hline & Oculina patagonica & $\begin{array}{l}\text { Temperate } \\
\text { region }\end{array}$ & $\begin{array}{l}\text { Kramarsky-Winter et al. } \\
\text { (1997) }\end{array}$ & & \\
\hline $\begin{array}{l}\text { High nutrient } \\
\text { concentrations }\end{array}$ & Acropora tenuis & Tropics & Yuyama et al. (2012) & Unlikely & $\begin{array}{l}\text { Nitrate concentration }(0.1-5.9 \mathrm{mg} / \\
\text { 1) exceeded natural values } \\
\text { (Comau Fjord: } 0.18-1.1 \mathrm{mg} / \mathrm{l}) \\
95 \% \text { of the time, however, } \\
\text { remained stable (no sudden } \\
\text { increases) over the entire } \\
\text { observation period and was within } \\
\text { the acceptable range for coral } \\
\text { husbandry (Borneman } 2008) \text {. As } \\
\text { the other coral individuals } \\
\text { remained unaffected, an effect of } \\
\text { nitrate is unlikely. In addition, } \\
\text { warm water scleractinians are } \\
\text { optimally maintained at } 5-10 \mathrm{mg} \\
\text { nitrate/l. Phosphate concentration } \\
\text { (0.06-0.28 mg/l) was in the } \\
\text { natural range (Comau Fjord: } \\
0.12-0.36 \text { mg/l) }\end{array}$ \\
\hline
\end{tabular}


Table 1 continued

\begin{tabular}{|c|c|c|c|c|c|}
\hline Stressor & Species & $\begin{array}{l}\text { Climatic } \\
\text { zone }\end{array}$ & Reference & $\begin{array}{l}\text { Probability for } \\
\text { the present } \\
\text { event }\end{array}$ & Justification \\
\hline \multirow{2}{*}{$\begin{array}{l}\text { Other } \\
\text { allelopathic } \\
\text { effects }\end{array}$} & Tubastraea coccinea & Tropics & $\begin{array}{l}\text { Capel et al. (2014), Algae: } \\
\text { pers. comm. K. Capel }\end{array}$ & \multirow[t]{2}{*}{ Very unlikely } & \multirow[t]{2}{*}{$\begin{array}{l}\text { Autotrophs cannot grow in the } \\
\text { system as it is permanently dark }\end{array}$} \\
\hline & Pocillopora damicornis & & Sin et al. (2012) & & \\
\hline $\begin{array}{l}\text { Presence of } \\
\text { synthetic } \\
\text { toxins }\end{array}$ & Pocillopora damicornis & Tropics & Wecker et al. (2018) & Very unlikely & $\begin{array}{l}\text { These substances are not used in or } \\
\text { near the aquarium unit }\end{array}$ \\
\hline High/low food & $\begin{array}{l}\text { Mussa angulosa } \\
\text { Pocillopora damicornis } \\
\text { Not defined } \\
\text { Astroides calycularis }\end{array}$ & $\begin{array}{l}\text { Temperate } \\
\text { region }\end{array}$ & $\begin{array}{l}\text { Goreau et al. (1971) } \\
\text { Richmond (1985) } \\
\text { Goreau and Goreau (1959) } \\
\text { Serrano et al. (2018) }\end{array}$ & Very unlikely & $\begin{array}{l}\text { Fed three times a week with live } \\
\text { Artemia salina nauplii, with the } \\
\text { spacing of the corals greater than } \\
\text { their diameter with expanded } \\
\text { tentacles, additionally each coral } \\
\text { specimen was handfed once a } \\
\text { week with a juvenile krill. } \\
\text { Furthermore, it is likely that the } \\
\text { water contained other food } \\
\text { resources such as dissolved and } \\
\text { particulate organic matter and } \\
\text { micro-organisms. As the other } \\
\text { coral individuals remained } \\
\text { unaffected, an effect of starvation/ } \\
\text { lack of nutritional diversity is } \\
\text { unlikely }\end{array}$ \\
\hline
\end{tabular}

anemones expel filament ends (acontia) through body wall openings (cinclides) (Manuel 1988). The perforations of the coral body wall likely affected the hydroskeleton supporting the body and tentacles of attached polyps, causing the rather retracted state (Fig. 2c). It is also likely that the impaired hydroskeleton prevented the reattachment of the polyps. Accordingly, stereomicroscopical observations confirmed no signs of skeleton precipitation under the detached polyps within the four-week (circuit A) and seven-month (circuit B) observation period, respectively, similarly to the Mediterranean scleractinian Astroides calycularis ( $\sim 12$-week observation; Serrano et al. 2018). By contrast, a small portion of bailed-out polyps of the tropical coral Seriatopora hystrix was able to initiate skeletogenesis as early as nine days after detachment (Sammarco 1982).

Some of the C. huinayensis dropouts attached to the glass with their tentacles. However, we have no evidence for resettlement on the glass, although $C$. huinayensis larvae settle on it successfully. The swimming anemone Stomphia coccinea is able to routinely detach and reattach to substrate (Robson 1961) and may serve as a model for polyp detachment/reattachment. Before adhesion, its pedal disc becomes sticky due to the discharge of nematocysts (Ellis et al. 1969). The latter may be lacking in the aboral calicoblastic ectoderm of dropped out $C$. huinayensis. Indeed, after settlement of scleractinian planula larvae, the aboral ectoderm undergoes ultrastructural changes including the loss of secretory cells and nematocysts (Vandermeulen 1975). While it is uncertain whether the detached $C$. huinayensis are able to restore this capacity beyond our observation period (seven months), we cannot rule out this possibility, given that expelled polyps of the tropical scleractinian coral Tubastraea coccinea have been shown to resettle after seven months (Capel et al. 2014).

If we assume that reattachment beyond our observation period might be possible, and because coral tissue is only slightly denser than seawater, we can suppose that in Comau Fjord dropouts may potentially drift with the currents, reach new habitats, resettle and reproduce. Sinking rate was $2.6 \pm 0.3 \mathrm{~cm} \mathrm{~s}^{-1}$. Tidally corrected current velocities of $5 \mathrm{~cm} \mathrm{~s}^{-1}$ (maximum $15 \mathrm{~cm} \mathrm{~s}^{-1}$ ) were recorded in the vicinity of the coral banks (unpubl. data). Considering the steep walls and the species' distribution to at least 265 m (Häussermann and Försterra 2007), polyps dropped out at $20 \mathrm{~m}$ water depth may potentially drift lateral up to $3.7 \mathrm{~km}$ until they reach $265 \mathrm{~m}$.

No direct evidence for polyp dropout was found in situ, but the partially detached stage, which precedes dropout over a longer period of time (twelve weeks for specimen \#5 in vitro), provided indirect evidence for dropout in natural field populations of $C$. huinayensis. In Comau Fjord, we documented partial polyp dropout in $1.4 \pm 0.8 \%$ of the polyps (six phototransects, total number of polyps analysed: 9322). Partially detached polyps were detected at both sites $(1.3 \pm 1.1 \%$ of the polyps at Cross-Huinay 
North, $1.5 \pm 0.5 \%$ of the polyps at Liliguapi) and did not follow a common pattern in terms of frequency over the three seasons analysed. These field observations provide a strong indication that polyp dropout is a process which occurs naturally, however, under normal environmental conditions in only a few individuals. Thus, sexual dispersal apparently dominates over the asexual one (here drift of dropouts), similar to the tropical scleractinian coral Pocillopora meandrina (Magalon et al. 2005).

Although the respective five aquarium specimens did not show any external signs of physical stress or disease during the $>20$ months maintenance period and also shortly before the polyp dropout, the possibility that some unmonitored external agent may have accounted for the observed changes cannot be excluded. It is unlikely that the removal process of the former recruits and the collection of adults had an impact 20 months after the transfer, especially as the corals grew as expected and partial detachment, indicative of imminent dropout, was also observed in situ. Furthermore, the lack of light during the maintenance period hardly seems to be a trigger, since only $6 \%$ of the aquarium corals showed symptoms of dropout. Moreover, partially detached corals were observed in situ, exposed to a light-dark cycle even under summer conditions. Weekly monitoring of water parameters did not reveal changes in the physico-chemical environment at the time or twelve weeks prior to the event (ANOVA $p>0.05$, Online supplementary material 1, Laudien et al. 2018). In contrast to Seriatopora hystrix and Pocillopora damicornis, where a stress-induced dissociation of $100 \%$ of the polyps was observed within $3 \mathrm{~d}$ (Sammarco 1982) and $6 \mathrm{~d}$, respectively (Fordyce et al. 2017), only a small percentage of the $C$. huinayensis polyps showed symptoms of dropout (6\%) over the six years observation period. The remainder showed no sign of impairment. Potential stressors are unlikely to have triggered the polyp dropout (Online supplementary material 1), suggesting an endogenous trigger in individual $C$. huinayensis.

Analogous to some anemone species that may temporarily or permanently lift off the bottom (Riemann-Zürneck 1998; Bedgood et al. 2020) and indeed actively swim in response to abiotic or biotic cues (for review, see Riemann-Zürneck 1998), polyp dropout may help C. huinayensis populate new regions, provided the dropout polyps are able to reattach or perform a lifestyle such as the one described as a 'straying predator' for Korsaranthus natalensis (Riemann-Zürneck 1998; Riemann-Zürneck and Griffiths 1999). Thus, polyp dropout allows the coral species to colonize new areas, even if the population is unable to complete its sexual reproductive life cycle (Honnay and Bossuyt 2005) or if recruitment fails (Warner and Chesson 1985). This process may favour well-adapted genotypes even in the absence of moderate to high levels of disturbance (Miller and Ayre 2004; Foster et al. 2007). Moreover, colonizing new areas is decoupled from the reproductive season or possible unfavourable recruitment conditions (e.g. release of larva, when food is rare). Furthermore, it is well known that scleractinian corals spend a considerable amount of their energy on calcification. Corals that were experimentally not allowed to calcify diverted their energy into somatic growth (Fine and Tchernov 2007). By analogy, dropout could be the result of the coral allocating more energy into reproduction, i.e. less into calcification - thus losing contact with its base. It would be interesting to know how 'fecund' the dropouts are compared to attached polyps. Further studies should be carried out to understand, which variable(s) exert the behaviour, and to confirm $C$. huinayensis polyp dropout in nature. If so, are the dropouts able to survive, form new skeletons and ensure the survival of their genotype?

As a new form of reverse development, polyp dropout results in scleractinian polyps surviving without their skeleton for several weeks. Similar processes have been hypothesized to be key in the survival of 'anemone-like' ancestors of Scleractinia through periods of hostile conditions including the Permian-Triassic mass extinction according to Stanley's 'naked coral hypothesis' (2003). Evolutionary advantage of polyp dropout, and polyp detachment in general, remains to be shown.

Supplementary Information The online version contains supplementary material available at https://doi.org/10.1007/s00338021-02148-0.

Acknowledgements This study was supported by BMBF (grant01DN13029), National Geographic Society (grant-EC-56391R-19), Fondecyt (grant 1201717), DAAD (grant-91608520), ANID DAADCONICYT Doctoral scholarship with bilateral agreement (grant62170011) and the Alfred-Wegener-Institut Helmholtz-Zentrum für Polar- und Meeresforschung (PACES II, DACCOR, and the programme 'Changing Earth - Sustaining our Future', Topic 4.2 and 6.1). We thank Christopher Brunner, Svantje Gottschlich and Erik Wurz for diving and sampling assistance; Julian Bartsch, Anita Hartig, Ulrike Holtz, Paul Kluwer, Esther Lüdke and Janis Müller for maintenance of the corals; and the staff of the Huinay Scientific Field Station for field support. We thank two anonymous reviewers for their valuable suggestions which helped to improve the paper. Specimens were exported from Chile under CITES permits 14CL000003WS, 14CL000014WS, 15CL000004WS and imported to Germany under E00154/14, E00095/15 and E00725/15. This is publication no. 178 of the Huinay Scientific Field Station.

Funding Open Access funding enabled and organized by Projekt DEAL.

\section{Declarations}

Conflict of interest On behalf of all authors, the corresponding author states that there is no conflict of interest.

Open Access This article is licensed under a Creative Commons Attribution 4.0 International License, which permits use, sharing, 
adaptation, distribution and reproduction in any medium or format, as long as you give appropriate credit to the original author(s) and the source, provide a link to the Creative Commons licence, and indicate if changes were made. The images or other third party material in this article are included in the article's Creative Commons licence, unless indicated otherwise in a credit line to the material. If material is not included in the article's Creative Commons licence and your intended use is not permitted by statutory regulation or exceeds the permitted use, you will need to obtain permission directly from the copyright holder. To view a copy of this licence, visit http://creativecommons. org/licenses/by/4.0/.

\section{References}

Bedgood SA, Bracken ME, Ryan WH, Levell ST, Wulff J (2020) Nutritional drivers of adult locomotion and asexual reproduction in a symbiont-hosting sea anemone Exaiptasia diaphana. Mar Biol 167:1-12

Borneman E (2008) Introduction to the husbandry of corals in aquariums: a review. Publ Aquar Husb Series 2:3-14

Cairns SD (1988) Asexual reproduction in solitary Scleractinia. In: Proceedings sixth international coral reef symposium, Townsville, pp 641-646

Cairns SD, Häussermann V, Försterra G (2005) A review of the Scleractinia (Cnidaria: Anthozoa) of Chile, with the description of two new species. Zootaxa 1018:15-46

Capel KCC, Migotto AE, Zilberberg C, Kitahara MV (2014) Another tool towards invasion? Polyp "bail-out" in Tubastraea coccinea. Coral Reefs 33:1165

Coppari M, Mestice F, Betti F, Bavestrello G, Castellano L, Bo M (2019) Fragmentation, re-attachment ability and growth rate of the Mediterranean black coral Antipathella subpinnata. Coral Reefs 38:1-14

Dahl MP, Pereyra RT, Lundälv T, André C (2012) Fine-scale spatial genetic structure and clonal distribution of the cold-water coral Lophelia pertusa. Coral Reefs 31:1135-1148

Ellis VL, Ross DM, Sutton L (1969) The pedal disc of the swimming sea anemone Stomphia coccinea during detachment, swimming, and resettlement. Can J Zool 47:333-342

Fillinger L, Richter C (2013) Vertical and horizontal distribution of Desmophyllum dianthus in Comau Fjord, Chile: a cold-water coral thriving at low $\mathrm{pH}$. Peer J 1:e194

Fine M, Tchernov D (2007) Scleractinian coral species survive and recover from decalcification. Science 315(5820):1811-1811

Fordyce AJ, Camp EF, Ainsworth TD (2017) Polyp bailout in Pocillopora damicornis following thermal stress. F1000Research, 6

Foster NL, Baums IB, Mumby PJ (2007) Sexual vs. asexual reproduction in an ecosystem engineer: the massive coral Montastraea annularis. J Anim Ecol 76:384- 391

Goreau TF, Goreau NI (1959) The physiology of skeleton formation in corals. II. Calcium deposition by hermatypic corals under various conditions in the reef. Biol Bull 117(2):239-250

Goreau TF, Gorea NI, Yonge CM (1971) Reef corals: Autotrophs or heterotrophs?. Biol Bull 141:247-260

Häussermann V, Försterra G (2007) Large assemblages of cold-water corals in Chile: a summary of recent findings and potential impacts. Bull Mar Sci 81:195-207

Häussermann V, Försterra G (2009) Marine benthic fauna of Chilean Patagonia. Nature in Focus, Santiago

Honnay O, Bossuyt B (2005) Prolonged clonal growth: Escape route or route to extinction?. Oikos 108:427-432

Jantzen C, Häussermann V, Försterra G, Laudien J, Ardelan M, Maier S, Richter C (2013) Occurrence of a cold-water coral along natural $\mathrm{pH}$ gradients (Patagonia, Chile.) Mar Biol 160:2597-2607

Kramarsky-Winter E, Fine M, Loya Y (1997) Coral polyp expulsion. Nature 387(6629):137-137

Kružić P (2007) Polyp expulsion of the coral Cladocora caespitosa (Anthozoa, Scleractinia) in extreme sea temperature conditions. Nat Croat 16:211-214

Kvitt H, Kramarsky-Winter E, Maor-Landaw K, Zandbank K, Kushmaro A, Rosenfeld H, Fine M, Tchernov D (2015) Breakdown of coral colonial form under reduced $\mathrm{pH}$ conditions is initiated in polyps and mediated through apoptosis. Proc Natl Acad Sci USA 112(7):2082-2086

Laudien J, Häussermann V, Försterra G, Göhlich H (2014) Physical oceanographic profiles of seven CTD casts from Gulf of Ancud into Comau Fjord in 2014. PANGAEA. https://doi.org/10.1594/ PANGAEA.832187

Laudien J, Holtz U, Heran T, Richter C (2018) Water parameters of the cold-water experimental aquarium system at AWI in 2017/2018. Pangaea. https://doi.org/10.1594/PANGAEA.895906

Laudien J, Heran T, Hartig A, Bartsch J, Kuwer P, Häussermann V, Försterra G, Schmidt-Grieb G, Richter C (2019) Photographs of cold-water scleractinian corals maintained in the AWI experimental aquarium system. Pangaea. https://doi.pangaea.de/10. 1594/PANGAEA.900439

Goff-Vitry Le MC, Pybus OG, Rogers AD (2004) Genetic structure of the deep-sea coral Lophelia pertusa in the northeast Atlantic revealed by microsatellites and internal transcribed spacer sequences. Mol Ecol 13:537-549

Liu C, Cheng SH, Lin S (2020) Illuminating the dark depths inside coral. Cell Microbiol 22(1):e13122

Manuel RL (1988) British Anthozoa (revised). EJ Brill, Leiden

Magalon H, Adjeroud M, Veuille M (2005) Patterns of genetic variation do not correlate with geographical distance in the reefbuilding coral Pocillopora meandrina in the South Pacific. Mol Ecol 14:1861-1868

Miller KJ, Ayre DJ (2004) The role of sexual and asexual reproduction in structuring high latitude populations of the reef coral Pocillopora damicornis. Heredity 92:557-568

Piraino S, Boero F, Aeschbach B, Schmid V (1996) Reversing the life cycle: medusae transforming into polyps and cell transdifferentiation in Turritopsis nutricula (Cnidaria, Hydrozoa). Biol Bull (woods Hole) 190:302-312

Piraino S, De Vito D, Schmich J, Bouillon J, Boero F (2004) Reverse development in Cnidaria. Can J Zool 82:1748-1754

Rakka M, Bilan M, Godinho A, Movilla J, Orejas C, Carreiro-Silva M (2019) First description of polyp bailout in cold-water octocorals under aquaria maintenance. Coral Reefs 38:15-20

Richmond R (1985) Reversible metamorphosis in coral planula larvae. Mar Ecol Prog Ser 22:181-185

Richmond RH, Hunter CL (1990) Reproduction and recruitment of corals: comparisons among the Caribbean, the Tropical Pacific, and the Red Sea. Mar Ecol Prog Ser 60:185-203

Riemann-Zürneck K (1998) How sessile are sea anemones? A review of free-living forms in the Actiniaria Cnidaria: Anthozoa. Mar Ecol 19:247-261

Riemann-Zürneck K, Griffiths CL (1999) Korsaranthus natalensis (Carlgren, 1938) nov. comb. (Cnidaria: Actiniaria) a mobile sea anemone attacking octocorals. Afr Zool 34:190-196

Roberts JM, Wheeler AJ, Freiwald A, Cairns S (2009) Cold-water corals - the biology and geology of deep-sea coral habitats Cambridge University Press Cambridge

Robson EA (1961) The swimming response and its pacemaker system in the anemone Stomphia coccinea. J Exp Biol 38:685-694

Sammarco PW (1982) Polyp bail-out: an escape response to environmental stress and a new means of reproduction in corals. Mar Ecol Prog Ser 10:57-65 
Sellanes J, Quiroga E, Neira C (2008) Megafauna community structure and trophic relationships at the recently discovered Concepción Methane Seep Area, Chile, $\sim 36^{\circ}$ S ICES. J Mar Sci 65:1102-1111

Serrano E, Coma R, Inostroza K, Serrano O (2018) Polyp bail-out by the coral Astroides calycularis (Scleractinia, Dendrophylliidae). Mar Biodivers 48:1661-1665

Shapiro OH, Kramarsky-Winter E, Gavish AR, Stocker R, Vardi A (2016) A coral-on-a-chip microfluidic platform enabling liveimaging microscopy of reef-building corals. Nat Commun 7:10860

Sin LC, Walford J, Goh BPI (2012) The effect of benthic macroalgae on coral settlement. In: Siang TK (ed) Contributions to Marine Science: a commemorative volume celebrating 10 years of research on St John's Island. National University of Singapore, pp 89-93

Silva N (2008) Dissolved oxygen, $\mathrm{pH}$, and nutrients in the austral Chilean channels and fjords. Progress in the oceanographic knowledge of Chilean interior waters, from Puerto Montt to Cape Horn, 37

Stanley GD (2003) The evolution of modern corals and their early history Earth. Sci Rev 60:195-225

Tokuda Y, Haraguchi H, Ezaki Y (2017) First real-time observation of transverse division in azooxanthellate scleractinian corals. Sci Rep 7(1):1-10

Vandermeulen JH (1975) Studies on reef corals. III. Fine structural changes of calicoblast cells in Pocillopora damicornis during settling and calcification. Mar Biol 31:69-77
Warner RR, Chesson PL (1985) Coexistence mediated by recruitment fluctuations - a field guide to the storage effect. Am Nat 125:769-787

Wecker P, Lecellier G, Guibert I, Zhou Y, Bonnard I, BerteauxLecellier V (2018) Exposure to the environmentally-persistent insecticide chlordecone induces detoxification genes and causes polyp bail-out in the coral $P$. damicornis. Chemosphere 195:190-200

Wells CD, Tonra KJ (2020) Polyp bailout and reattachment of the abundant Caribbean octocoral Eunicea flexuosa. Coral Reefs 40:27-30

Wilson JB (1979) 'Patch' development of the deep-water coral Lophelia pertusa (L.) on Rockall Bank. J Mar Biol Assoc UK 59:165-177

Wurz E (2014) Autökologie der Kaltwassersteinkoralle Caryophyllia huinayensis aus der patagonischen Fjordregion. MSc thesis, Alfred-Wegener-Institut and Universität Rostock, p 73

Yuyama I, Ito Y, Watanabe T, Hidaka M, Suzuki Y (2012) Differential gene expression in juvenile polyps of the coral Acropora tenuis exposed to thermal and chemical stresses. J Exp Mar Biol Ecol 430-431:17-24

Publisher's Note Springer Nature remains neutral with regard to jurisdictional claims in published maps and institutional affiliations. 